\title{
Bean yield under irrigation depths and tillage systems ${ }^{1}$
}

\author{
Giuliani do Prado ${ }^{2}$, Adriano Catossi Tinos 2 , \\ Rafael de Almeida Schiavon ${ }^{2}$, Denise Mahl ${ }^{2}$
}

\section{ABSTRACT}

Yield response data of crops to soil and water management are vital for maximizing profits. This research aimed to evaluate the yield of the 'IPR Andorinha' bean cultivar under distinct irrigation depths $(0,25,48,100$ and $130 \%$ of the net irrigation depth) and tillage systems (no-tillage and conventional tillage), during the Brazilian fall season. The experimental design was in strips with subdivided plots and four replications, with the factor soil management in the plot and irrigation depths in the subplot. No-tillage had an average grain yield $26.5 \%$ higher than that of the conventional tillage. Both the soil management treatments presented a quadratic response $\left(\mathrm{R}^{2}>90 \%\right)$ to the irrigation depths applied, and the maximum yields were reached at $63.8 \%\left(\mathrm{y}=2,452 \mathrm{~kg} \mathrm{ha}^{-1}\right)$ and $81.8 \%\left(\mathrm{y}=1,789 \mathrm{~kg} \mathrm{ha}^{-1}\right)$ of the irrigation depth, respectively for the no-tillage and conventional tillage. However, the irrigation of bean cropped in the Brazilian fall season is not economically feasible for the no-tillage and conventional tillage when the price of the water millimeter is 43.19 and 33.27 times higher than the price of the bean kilogram, respectively, resulting in yields of 1,345.2 and $699.4 \mathrm{~kg} \mathrm{ha}^{-1}$.

KEYWORDS: Phaseolus vulgaris, no-tillage, conventional tillage.

\section{INTRODUCTION}

Bean is one of the main products in the Brazilian diet, and this commodity is a meaningful source of proteins (23.4-26.7\%) and micronutrients (iron and zinc contents that can satisfy, respectively, 20.3 and $19.8 \%$ of a person's daily demand) (Pereira et al. 2018).

In the 2018/2019 harvest, the Brazilian area cultivated with bean was 2.922 million hectares and the production 3.017 million tons, with the Paraná state accounting for a total cultivated area and production of 13.53 and $20.53 \%$, respectively (Conab 2020).

\section{RESUMO}

Produtividade de feijoeiro sob

lâminas de irrigação e sistemas de cultivo

Dados de produtividade das culturas em função do manejo do solo e da água são essenciais para a maximização dos lucros. Objetivouse avaliar a produtividade da cultivar de feijoeiro 'IPR Andorinha' sob diferentes lâminas de irrigação $(0,25,48,100$ e $130 \%$ da lâmina líquida de irrigação) e sistemas de cultivo (plantio direto e convencional), no outono. $\mathrm{O}$ delineamento experimental foi em faixas com parcelas subdivididas e quarto repetições, com o fator manejo do solo na parcela e lâminas de irrigação na subparcela. O plantio direto apresentou produtividade de grãos $26,5 \%$ superior à do convencional. Ambos os tratamentos para manejo do solo apresentaram resposta quadrática $\left(\mathrm{R}^{2}>90 \%\right)$ às lâminas de irrigação aplicadas, e as produtividades máximas foram alcançadas com $63,8 \%\left(y=2.452 \mathrm{~kg} \mathrm{ha}^{-1}\right)$ e $81,8 \%$ $\left(\mathrm{y}=1.789 \mathrm{~kg} \mathrm{ha}^{-1}\right)$ da lâmina líquida, respectivamente para o plantio direto e convencional. Entretanto, o cultivo irrigado do feijoeiro no outono não é economicamente viável no plantio direto e convencional quando o preço do milímetro de água for 43,19 e 33,27 vezes superior ao do quilograma de feijão, respectivamente, resultando em produtividades de 1.345,2 e 699,4 $\mathrm{kg} \mathrm{ha}^{-1}$.

PALAVRAS-CHAVE: Phaseolus vulgaris, plantio direto, plantio convencional.

In some Brazilian regions, depending on climatic conditions and water availability, bean can be grown in three different crops (Marco et al. 2012). In the northwestern Paraná state, due to the high temperatures $\left(>30^{\circ} \mathrm{C}\right)$ in the spring and summer seasons and the possibility of low temperatures in the winter $\left(<10{ }^{\circ} \mathrm{C}\right)$, only the cultivation in the fall season, or third crop, has been recommended (Caramori et al. 2001).

In the northwestern Paraná state, a sandy soil texture predominates, which may reach up to $90 \%$ of sand in particle-size analysis (Fidalski et al. 2013, Thomaz \& Fidalski 2020). This type of soil

\footnotetext{
${ }^{1}$ Received: July 16, 2021. Accepted: Nov. 26, 2021. Published: Dec. 10, 2021. DOI: 10.1590/1983-40632021v5169665.

${ }^{2}$ Universidade Estadual de Maringá, Departamento de Engenharia Agrícola, Cidade Gaúcha, PR, Brasil.

Email/ORCID: gprado@uem.br/0000-0001-5442-7446; actinos@uem.br/0000-0002-4019-1046; raschiavon@gmail.com/ 0000-0003-0222-7148; demahl@gmail.com/0000-0003-1868-8598.
} 
has a low capacity for holding water and nutrients and an extreme susceptibility to erosion. Thus, soil management practices such as no-tillage and crop rotation have been essential for its cultivation and conservation (Kassam et al. 2019, Telles et al. 2019).

Due to the low water holding capacity of sandy soils, even proper soil management and fertilization practices may compromise crop yields under water deficit (Fidalski \& Helbel Junior 2020). Volsi et al. (2020) carried out experiments in the northwest Paraná state with different crops associated with the no-tillage system and, because of the soil water availability, concluded that there is low profitability for the bean cultivation in this region without irrigation.

In crops such as bean, which has a shallow root system, the water deficit effect may be more severe, and the adoption of an irrigation system could be an alternative to increase this crop yield (Mahgoub et al. 2017). Faria et al. (2012), evaluating different irrigation managements for the bean crop, observed that cultivation under irrigation resulted in an average yield of $2,477 \mathrm{~kg} \mathrm{ha}^{-1}$. On the other hand, rain-fed bean provided only $383 \mathrm{~kg} \mathrm{ha}^{-1}$, representing a difference of $84.5 \%$.

Arguably, the yield of irrigated crops has been higher than that of rain-fed crops (Prado et al. 2021). However, in scenarios where water and energy costs are high, deficit irrigation management could be an alternative to achieve a maximum economic return, and the relation between crop yields and irrigation application depths (production function) is vital in this context (Mendoza-Pérez et al. 2016). Thus, this study aimed to evaluate the bean yield under irrigation application depths and soil management systems, during the Brazilian fall season.

\section{MATERIAL AND METHODS}

The experiment was carried out from March 23 to June 22 (2020), using the bean (Phaseolus vulgaris) 'IPR Andorinha' cultivar from the Instituto Agronômico do Paraná (Iapar), in the Arenito Caiuá region, at the Universidade Estadual de Maringá, in Cidade Gaúcha, Paraná state, Brazil (2322'30"'S, $52^{\circ} 56^{\prime} 00^{\prime \prime} \mathrm{W}$ and mean altitude of $404 \mathrm{~m}$ ). According to the Köppen climate classification (Alvares et al. 2013), the region is humid subtropical (Cfa), with relatively high temperatures and evenly distributed precipitation throughout the year. Nevertheless, the temperatures and rainfalls start decreasing in the fall season, ending at the lowest values in the winter (Bortoluzzi et al. 2019).

The soil of the experimental area is classified as Latossolo Vermelho Distrófico (Santos et al. 2018), or Rhodic Ferralsol (FAO 2015), with a sandy texture $[83 \%$ of sand (fine and coarse)], in the 0-0.20 m layer (Mioto et al. 2016). Previously (from January 10, 2019, to February 10, 2020), the area was grown with corn under no-tillage (Avena sativa straw) and conventional tillage. The soil chemical characterization (0-0.20 m layer) before the corn cultivation was as it follows: $\mathrm{pH}\left(\mathrm{H}_{2} \mathrm{O}\right)=5.60 ; \mathrm{pH}\left(\mathrm{CaCl}_{2}\right)=4.90$; potential acidity $(\mathrm{H}+\mathrm{Al})=2.74 \mathrm{cmol}_{\mathrm{c}} \mathrm{dm}^{-3}$ (SMP method); $\mathrm{Al}^{3+}=0.00 \mathrm{cmol}_{\mathrm{c}} \mathrm{dm}^{-3} ; \mathrm{Ca}^{2+}=1.45 \mathrm{cmol}_{\mathrm{c}} \mathrm{dm}^{-3} ;$ $\mathrm{Mg}^{2+}=0.48 \mathrm{cmol}_{\mathrm{c}} \mathrm{dm}^{-3}$ (extracted by $\mathrm{KCl} 1 \mathrm{~mol} \mathrm{~L}^{-1}$ ); $\mathrm{K}^{+}=0.19 \mathrm{cmol}_{\mathrm{c}} \mathrm{dm}^{-3} ; \mathrm{P}=7.82 \mathrm{mg} \mathrm{dm}^{-3}$ (extracted by Mehlich 1); $\mathrm{C}=7.78 \mathrm{~g} \mathrm{dm}^{-3}$ (Walkley-Black method).

According to Oliveira (2003), a soil base saturation of $70 \%$ has been recommended for corn and bean crops. Therefore, four months before running the corn experiment, in June 2019, a dolomitic limestone quantity of $1,712 \mathrm{~kg} \mathrm{ha}^{-1}(75 \%$ of relative power of total neutralization) was applied and incorporated into the soil (with plowing and harrowing), for the 0-0.20 m layer. Consequently, no liming was applied to the soil to perform the bean experiment.

On February 28 (2020), one application of the glyphosate herbicide was carried out $\left(4 \mathrm{~L} \mathrm{ha}^{-1}\right)$ for weeding control in the experimental area. Three weeks later, half of the area was mobilized to a depth of $0.20 \mathrm{~m}$, with a moldboard plow and leveling disc harrow, and the other half of the area was left to notillage cultivation.

On March 23 (2020), the bean seeds were treated with a systemic and contact fungicide/nematicide of benzimidazole and phenylpyridinylamine $\left(1.8 \mathrm{~mL} \mathrm{~kg}^{-1}\right.$ of seeds). In that same day, the seeds were sown with a seeder, which had three sowing lines spaced $0.45 \mathrm{~m}$ apart. The equipment was calibrated to distribute 266,666 seeds ha ${ }^{-1}\left(12\right.$ seeds $\left.\mathrm{m}^{-1}\right)$ and $333 \mathrm{~kg} \mathrm{ha}^{-1}$ of fertilizer. An NPK (6-24-12) fertilizer was used, which, according to Oliveira (2003), provides a nutrient amount of $20 \mathrm{~kg} \mathrm{ha}^{-1}$ of $\mathrm{N}, 80 \mathrm{~kg} \mathrm{ha}^{-1}$ of $\mathrm{P}_{2} \mathrm{O}_{5}$ and $40 \mathrm{~kg} \mathrm{ha}^{-1}$ of $\mathrm{K}_{2} \mathrm{O}$. The surface nitrogen application was performed 20 days after the seed emergence, with $60 \mathrm{~kg} \mathrm{ha}^{-1}$ of $\mathrm{N}\left(133.33 \mathrm{~kg} \mathrm{ha}^{-1}\right.$ of urea). 
After seedling emergence ( 8 days after sowing), the experiment, with 40 plots, each with $2.7 \times 5.0 \mathrm{~m}\left(13.5 \mathrm{~m}^{2}\right)$ and six rows of plants, was established, following a strip plot design with subdivided plots, two factors and four replications. The treatments consisted of two soil management systems (conventional tillage and no-tillage) and five irrigation depths $(0,25,48,100$ and $130 \%$ of the net irrigation depth).

During the crop initial development, plant thinning was performed, maintaining a density of 240,000 plants $\mathrm{ha}^{-1}\left(10.8\right.$ plants $\left.\mathrm{m}^{-1}\right)$, and all the experimental plots were irrigated up to the fifteenth day after sowing, to provide the water demanded by the plants. Thus, a solid-set sprinkler irrigation system was installed, with sprinklers set up in a rectangular arrangement and spaced $12 \times 18 \mathrm{~m}$ apart.

When the plant density was set in the experiment, the application of different irrigation depths in the treatments started at 15 days after sowing. For that, a single pipeline with five sprinklers (line-source), installed in rising pipes $1.2-\mathrm{m}$ high from the soil surface and spaced $12 \mathrm{~m}$ apart, was left at one end of the experimental area. As the Agropolo ${ }^{\circledR}$ NY30 sprinkler, with $5.0 \times 4.6 \mathrm{~mm}$ nozzle diameters at a working pressure of $294 \mathrm{kPa}$, has a water distribution similar to the triangular geometric shape (Prado 2016), the net irrigation depth (NID) to raise the soil moisture to the field capacity was defined as treatment I3 (I3 = $100 \%$ of the NID). Consequently, from the treatment $\mathrm{I} 3$, three treatments were set with a lower irrigation depth $(\mathrm{I} 0=0 \%$; $\mathrm{I} 1=25 \%$; and $\mathrm{I} 2=$ $48 \%$ of the NID) and one with the highest irrigation level (I4 $=130 \%$ of the NID).

The irrigation management was employed in response to the weather, with meteorological data collected daily at a station located $50 \mathrm{~m}$ from the experimental area. Meteorological data of solar radiation; minimum, mean and maximum temperature; wind speed at $2 \mathrm{~m}$ above the ground; and relative humidity were used to calculate the reference evapotranspiration $\left(\mathrm{ET}_{0}\right)$, with the Penman-Monteith equation (Allen et al. 1998).

The crop coefficient $(\mathrm{Kc})$, given by the equation 1 (Allen et al. 1998), was used to calculate the crop evapotranspiration under standard conditions $\left(\mathrm{ETc}=\mathrm{ET}_{0} \times \mathrm{Kc}\right)$; and the water stress coefficient (ks), computed by the equation 2 (Prado et al. 2020), was used to calculate the crop evapotranspiration under soil water stress conditions $\left(\mathrm{ETc}_{\text {adj }}=\mathrm{ETc} \times \mathrm{ks}\right)$ :

$\mathrm{Kc}=\left\{\begin{array}{l}\mathrm{Kc} \leftarrow 0.4, \text { if } \mathrm{DAG} \leq 15 \\ \mathrm{Kc} \leftarrow 0.4+\frac{[0.75(\mathrm{DAG}-15)]}{25}, \text { if } 15<\mathrm{DAG}<40 \\ \mathrm{Kc} \leftarrow 1.15, \text { if } 40 \leq \mathrm{DAG} \leq 75 \\ \mathrm{Kc} \leftarrow 1.15+\frac{[0.3(\mathrm{DAG}-75)]}{15}, \text { if } 75<\mathrm{DAG} \leq 90\end{array}\right.$

$\mathrm{ks}=\left\{\begin{array}{l}\mathrm{ks} \leftarrow \frac{\ln \left(\mathrm{I}_{\mathrm{WA}}+1\right)}{\ln \left(\mathrm{I}_{\mathrm{WFC}}+1\right)}, \text { if } \mathrm{I}_{\mathrm{WWP}} \leq \mathrm{I}_{\mathrm{WA}} \leq \mathrm{I}_{\mathrm{WFC}} \\ \mathrm{ks} \leftarrow 1, \text { if } \mathrm{I}_{\mathrm{WFC}}<\mathrm{I}_{\mathrm{WA}} \leq \mathrm{I}_{\mathrm{Ws}} \\ \mathrm{ks} \leftarrow 0, \text { if } \mathrm{I}_{\mathrm{WA}} \leq \mathrm{I}_{\mathrm{WWP}}\end{array}\right.$

where Kc is the crop coefficient (decimal); DAG the period after germination (days); ks the water stress coefficient (decimal); $I_{\mathrm{WA}}$ the available soil water depth (mm); $I_{\mathrm{WFC}}$ the soil water depth in the field capacity $(\mathrm{mm}) ; \mathrm{I}_{\mathrm{wS}}$ the soil water depth in saturation $(\mathrm{mm})$; and $\mathrm{I}_{\mathrm{WwP}}$ the soil water depth at the permanent wilting point (mm).

In the soil water balance for irrigation management, data on soil moisture in saturation $\left(0.311 \mathrm{~m}^{3} \mathrm{~m}^{-3}\right)$, field capacity $\left(0.196 \mathrm{~m}^{3} \mathrm{~m}^{-3}\right)$ and wilting point $\left(0.066 \mathrm{~m}^{3} \mathrm{~m}^{-3}\right)$ were determined on the soil retention curve from the experimental area, respectively for soil water tensions of 0,6 and $1,500 \mathrm{kPa}$. The effective rooting depth was defined as $0.3 \mathrm{~m}$, and the soil water depletion fraction for no stress (p) was 0.4 . Therefore, the net irrigation depth to raise the soil moisture to field capacity (treatment I3) represented the sum of the $\mathrm{ETc}_{\text {adj }}$ minus the rainfall collected in the experimental area.

The total net irrigation depth was applied in the treatment I3, which served as a reference for the irrigation management. To control the irrigation depths applied in each treatment, the amounts of water were measured in $0.08 \mathrm{~m}$ diameter collectors, installed at a height of $1 \mathrm{~m}$ from the soil surface. Two rows of collectors set transversely to the direction of the experimental strips were used to determine the water application depth in each treatment.

During the experiment, at 19 and 38 days after sowing, hoeing and manual weeding were performed, respectively in the conventional tillage and no-tillage areas. For protection against fungal diseases and insect control, two pesticide applications were carried out at 30 and 46 days after sowing. The fungicide used was in the functional group of dithiocarbamates $\left(2 \mathrm{~kg} \mathrm{ha}^{-1}\right)$ and the insecticide was in the functional group of organophosphates $\left(1 \mathrm{~L} \mathrm{ha}^{-1}\right)$. 
The plants were harvested at 92 days after sowing (June 22, 2020), on the two central plant lines of each plot, corresponding to an area of $2.7 \mathrm{~m}^{2}(0.9 \times 3.0 \mathrm{~m})$. The samples were sent to the laboratory, where the grain yield and mass of 100 seeds were determined. Two grain samples from each experimental unit were taken and remained in an air circulation oven for 24 hours, at $105^{\circ} \mathrm{C}$, to determine the grain moisture on a wet basis. The moisture values were used to estimate the grain yield and mass of 100 seeds for $13 \%$ of moisture on a wet basis.

The data were submitted to analysis of variance (Anova) at $5 \%$ of significance by the $F$ test. In case of significant differences, regression analysis was applied to quantitative data and the Tukey test to qualitative data, both at $5 \%$ of probability. All the statistical analyses were performed employing the Sisvar software, version 5.3 (Ferreira 2011).

\section{RESULTS AND DISCUSSION}

Daily data of mean air temperature, solar radiation, rainfall and reference evapotranspiration observed during the experiment are shown in Figure 1. As the experiment was carried out in the fall season, there was a trend toward the air temperature values to decrease throughout the crop development. In the period between flowering and the end of ripening, the mean air temperature was $2.7^{\circ} \mathrm{C}$ lower than that of $21.3^{\circ} \mathrm{C}$ observed over the experiment, and the daily air temperature ranged from 13 to $26.7^{\circ} \mathrm{C}$. According to Marco et al. (2012), the optimum daily temperature for growing bean ranges between 15 and $20^{\circ} \mathrm{C}$.
The solar radiation had a mean value of 16.5 $\mathrm{MJ} \mathrm{m}^{-2}$ day $^{-1}$ and presented daily values of 2.924.8 $\mathrm{MJ} \mathrm{m}^{-2}$ day $^{-1}$ (Figure 1). However, throughout the flowering and end of ripening, this solar radiation was $21.4 \%$ lower. This reflected directly on the reference evapotranspiration, which had a mean value of $3.0 \mathrm{~mm} \mathrm{day}^{-1}\left(0.8\right.$ to $\left.5.3 \mathrm{~mm} \mathrm{day}^{-1}\right)$ in the total crop-growing period and a mean value of $2.2 \mathrm{~mm} \mathrm{day}^{-1}$ throughout the flowering and ripening stages. Transpiration represents plant hydraulic transport (Miralles et al. 2020), and when the crop is well developed and completely covers the soil, it becomes the main process (Allen et al. 1998); consequently, lower evapotranspiration values reduce the water and nutrients transported through the plant.

During the experiment (March 23 to June 22, 2020), twelve rainfall events happened, with values that ranged from 1 to $64.6 \mathrm{~mm}$, resulting in a total rainfall depth of $231 \mathrm{~mm}$ (Figure 1). Despite this amount of rain, half of the rainfall events occurred at intervals between 6 and 26 days, making irrigation essential for supplementing water to growing beans, especially in sandy soils like those in the Arenito Caiuá region. Bortoluzzi et al. (2019), carrying out a monthly rainfall analysis for that region, observed that, compared to the summer, in the fall months (April, May and June), there is a sharp decrease in the amount of rainfall, reaching the lowest values in the winter months.

The irrigation depths applied in the treatments are shown in Table 1 . The treatment I 3 received $100 \%$ of the estimated net irrigation depth to raise the soil moisture to field capacity. Over the total crop

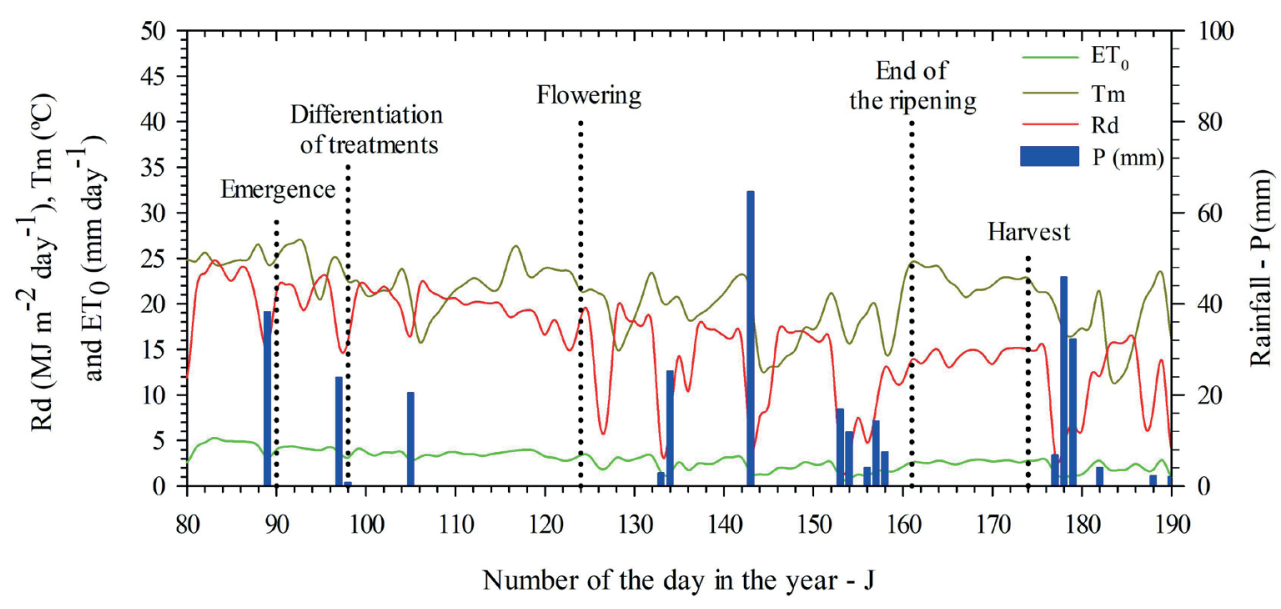

Figure 1. Variations of solar radiation $(\mathrm{Rs})$, mean air temperature $(\mathrm{Tm})$, reference evapotranspiration $\left(\mathrm{ET}_{0}\right)$ and rainfall $(\mathrm{P})$ during the experiment (Cidade Gaúcha, Paraná state, Brazil). 
Table 1. Data for the irrigation depth (I) treatments during the experiment.

\begin{tabular}{ccc}
\hline Treatments* & Total $(\mathrm{mm})$ & NID $^{* *}$ or I3 $(\%)$ \\
\hline I0 & 0 & 0 \\
I1 & 20 & 25 \\
I2 & 38 & 48 \\
I3 & 80 & 100 \\
I4 & 105 & 130 \\
\hline
\end{tabular}

* Depth irrigation levels (I0, I1, I2, I3 and I4); ** NID: net irrigation depth.

growing period, this treatment (I3) was applied at an irrigation depth $(\mathrm{I}=80 \mathrm{~mm})$ equal to $38.9 \%$ of the total crop evapotranspiration $\left(\mathrm{ETc}_{\mathrm{adj}}=206.7 \mathrm{~mm}\right)$. Pereira et al. (2014) pointed out that bean water requirements for a maximum production of a 90 to 120 -day crop vary between 300 and $500 \mathrm{~mm}$, depending on the climate. Nevertheless, even the reference evapotranspiration calculated $\left(\mathrm{ET}_{0}=274.3 \mathrm{~mm}\right)$ for the whole crop period was below the values suggested by the authors, becoming an unfavorable condition for the crop achieving its maximum yield.

The results of the means comparison analysis for the soil management factor are in Table 2. There was no statistical difference between the kind of soil management for the dependent variable mass of 100 seeds, and the overall mean was equal to $25.5 \mathrm{~g}$. Leal et al. (2019), when evaluating the performance of distinct bean cultivars to the nitrogen applied, observed that the nitrogen rates did not present statistical differences for the mass of 100 seeds, and that, for the 16 cultivars evaluated, the values varied between 23.7 and $29.53 \mathrm{~g}$, and the 'IPR Andorinha' cultivar presented a mean value of $26.72 \mathrm{~g}$.

Analyzing the grain yield within each irrigation depth (Table 2), the no-tillage system superiority over the management with soil mobilization was

Table 2. Grain yield and mass of 100 seeds (M100), as a function of soil management (conventional tillage - CT and notillage - NT), in each irrigation depth (I).

\begin{tabular}{ccccc}
\hline Irrigation & \multicolumn{2}{c}{ Grain yield $\left(\mathrm{kg} \mathrm{ha}^{-1}\right)$} & \multicolumn{2}{c}{$\mathrm{M} 100(\mathrm{~g})$} \\
\cline { 2 - 5 } depth $(\mathrm{mm})$ & $\mathrm{CT}$ & $\mathrm{NT}$ & $\mathrm{CT}$ & $\mathrm{NT}$ \\
\hline $\mathrm{I} 0=0$ & $755.8 \mathrm{a}^{*}$ & $1,332.5 \mathrm{~b}$ & $25.9 \mathrm{a}$ & $27.4 \mathrm{a}$ \\
$\mathrm{I} 1=20$ & $1,104.7 \mathrm{a}$ & $2,182.9 \mathrm{~b}$ & $26.4 \mathrm{a}$ & $27.6 \mathrm{a}$ \\
$\mathrm{I} 2=38$ & $1,737.3 \mathrm{a}$ & $2,186.0 \mathrm{~b}$ & $25.1 \mathrm{a}$ & $26.3 \mathrm{a}$ \\
$\mathrm{I} 3=80$ & $1,704.5 \mathrm{a}$ & $2,235.5 \mathrm{~b}$ & $23.7 \mathrm{a}$ & $25.8 \mathrm{a}$ \\
$\mathrm{I} 4=105$ & $1,405.6 \mathrm{a}$ & $1,194.6 \mathrm{a}$ & $22.8 \mathrm{a}$ & $22.3 \mathrm{a}$ \\
\hline Mean & $1,341.6 \mathrm{a}$ & $1,826.3 \mathrm{~b}$ & $24.8 \mathrm{a}$ & $25.9 \mathrm{a}$ \\
\hline
\end{tabular}

* Means followed by the same letter in the row do not differ by the Tukey test at the 0.05 probability level. evident; the exception was for the treatment I4, where the yields in both systems were statistically equal ( $p>0.05)$. Prado et al. (2020), while evaluating the grain yield of corn under irrigation and soil management in the Arenito Caiuá region, observed that the conventional tillage and no-tillage systems had no significant difference in corn yield. This may be related to the crop season (spring/summer), which has a higher amount of rainfall, and the corn rooting zone, which allowed the extraction of water from the deepest soil layers.

In addition to the higher bean grain yield provided by the no-tillage system, this soil management should be preferred in the Arenito Caiuá region, due to the lower water and nutrient holding capacity and the high susceptibility to erosion that these sandy soils have. Volsi et al. (2020), studying the economic profitability of no-tillage systems with crop rotation for three years, concluded that crop rotation systems using a larger number of crops may bring profits to the farmers in the Arenito Caiuá region, and bean can be an option for the crop growing period of the fall/winter.

The grain yield and mass of 100 seeds values, as a function of the percentage of net irrigation depth applied, are depicted in Figure 2. The increase in the irrigation application depth resulted in a quadratic grain yield response for both the soil management systems (Figure 2A). The adjusted quadratic polynomial equations represent more than $90 \%$ $\left(\mathrm{R}^{2}>0.9\right)$ of the bean grain yield response to the irrigation depths.

The rates of change in grain yield, related to the irrigation application depth $\left(\mathrm{dy} \mathrm{dx}^{-1}\right)$, decreased linearly and reflected in the grain yield response to increasing the irrigation depth. Irrigation depths of $63.8 \%\left(\mathrm{y}=2,452 \mathrm{~kg} \mathrm{ha}^{-1}\right)$ and $81.8 \%(\mathrm{y}=$ $\left.1,789 \mathrm{~kg} \mathrm{ha}^{-1}\right)$, respectively for the no-tillage and conventional tillage systems (optimum depth), resulted in rates of change equal to zero and the highest yields (maximum yield). On the other hand, for irrigation depth percentages below these values, the rates of change were positive, and increasing irrigation depths may raise the grain yield (Figure 2A). However, irrigation depths greater than the optimum depths had negative rates of change, leading to a reduction in grain yield, due to the excess of water applied.

The maximum grain yield value reached in the no-tillage system, which has been preferred over the 

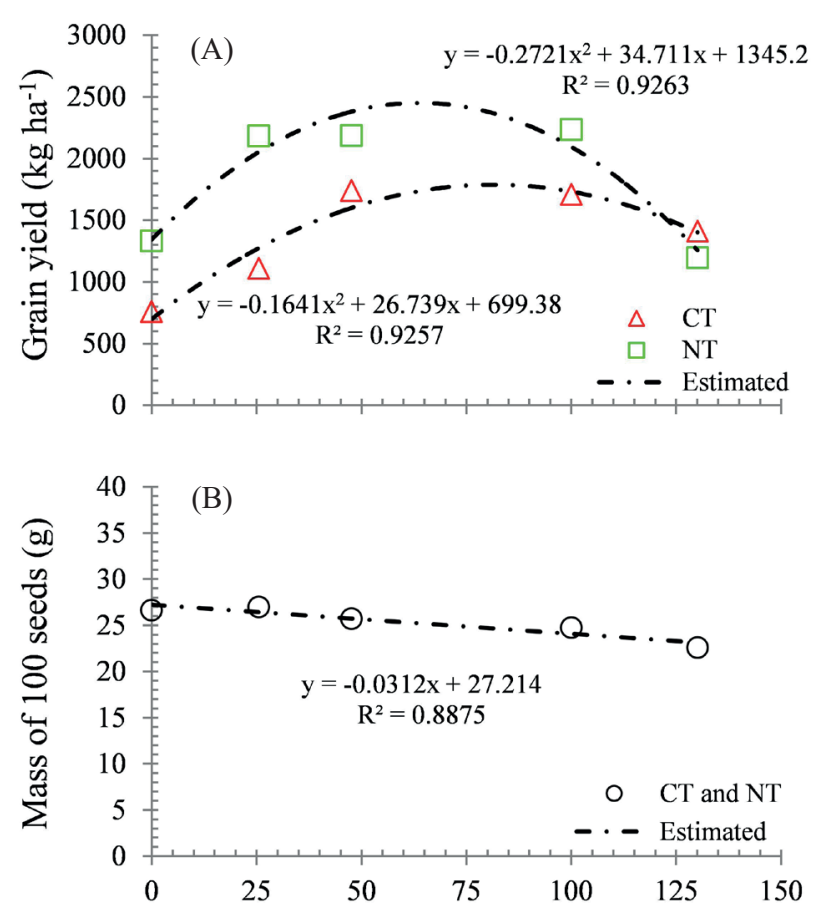

Irrigation depth (NID\%)

Figure 2. Bean grain yield (A) and mass of 100 seeds (B), as a function of the net irrigation depth percentage (NID\%), for conventional tillage (CT) and no-tillage (NT).

soil mobilization system, is close to that found by Leal et al. (2019). These authors, evaluating different cultivars of irrigated bean in the winter under notillage systems, had a grain yield of 2,304 $\mathrm{kg} \mathrm{ha}^{-1}$ with the 'IPR Andorinha' cultivar, under a nitrogen rate of $120 \mathrm{~kg} \mathrm{ha}^{-1}$. Nevertheless, Kotz-Gurgacz et al. (2018), testing the 'Pérola' bean cultivar under notillage system and nitrogen rates, in two crop periods, reached grain yields of 3,342 and 2,699 $\mathrm{kg} \mathrm{ha}^{-1}$, respectively in the warmer (August to November) and colder (February to May) periods, in the irrigated treatments.

As the maximum yields were found with irrigation depth under the net irrigation depth to raise the soil moisture to the field capacity (treatment I3), the crop coefficients (Kc) employed could be lower. The crop coefficient values may vary depending on the crop, climate and management conditions (Allen et al. 1998).

Soratto et al. (2003), assessing the bean grain yield in the winter under no-tillage system and various irrigation depths, observed that the grain yield $\left(y=2,456 \mathrm{~kg} \mathrm{ha}^{-1}\right)$ was obtained with a reduction of
$25 \%$ in the crop coefficient values suggested by Allen et al. (1998), and there was no statistical difference for the yields achieved with the greater irrigation depths. Arf et al. (2004) also noticed no statistical differences within irrigation depth treatments $\left(0.75^{*} \mathrm{Kc}, 1 * \mathrm{Kc}\right.$ and $1.25^{*} \mathrm{Kc}$ ) for the grain yield of bean cropped in the winter, for two years in a row, which resulted in yield values of 1,970 and $1,580 \mathrm{~kg} \mathrm{ha}^{-1}$, respectively in 2001 and 2002.

Fischer Filho \& Zocoler (2016), carrying out an experiment in a greenhouse with bean in pots, set crop coefficients for the growing period between flowering and ripening that varied from 1.06 to 1.13. However, crop coefficients for field conditions under different climate, water and soil management types are rare in the literature, and these data are essential for an accurate irrigation depth quantification.

Increasing the irrigation depth resulted in a linear decrease of $3.12 \%\left(\mathrm{R}^{2}=88.75 \%\right)$ in the mass of 100 seeds, which ranged from $27.2 \mathrm{~g}$ (I0) to $23.2 \mathrm{~g}$ (I4) (Figure 2B). While evaluating the 'Pérola' bean cultivar under different nitrogen rates, Moreira et al. (2013) observed no statistical difference for the dependent variable mass of 100 seeds, despite these values varying from 20.24 to $27.33 \mathrm{~g}$. According to the aforementioned authors, this agronomic characteristic has small variations with changes in the environment.

A grain yield rate related to the irrigation depth applied $\left(\mathrm{dy}_{\mathrm{dx}} \mathrm{x}^{-1}\right)$ equal to the ratio of prices between water (px) and bean (py) allows for computing the crop economic yield (Conceição et al. 2018). When the water depth applied has no cost $\left(\mathrm{px} \mathrm{py}^{-1}=\mathrm{dy} \mathrm{dx} \mathrm{x}^{-1}=0\right)($ Figure 3A), it could be economically profitable to reach the maximum grain yield (Figure 3B) at 63.8 and $81.8 \%$ of the net irrigation depth, respectively for the no-tillage and conventional tillage systems.

In irrigated bean production scenarios, when the price ratio between water and bean (px $\mathrm{py}^{-1}$ ) presents values higher than zero, it could be economically profitable to perform deficit irrigation and apply a fraction of the irrigation depth. Hence, in the conventional tillage and no-tillage systems, respectively when the costs to pump $1 \mathrm{~mm}$ of water are 33.27 and 43.19 times higher than $1 \mathrm{~kg}$ of bean (Figure 3A), working with rain-fed agriculture and having decreases in grain yield of $60.9 \%(\mathrm{y}=$ $\left.699.4 \mathrm{~kg} \mathrm{ha}^{-1}\right)$ and $45.1 \%\left(\mathrm{y}=1,345.2 \mathrm{~kg} \mathrm{ha}^{-1}\right)$ could be economically profitable (Figure 3B). 


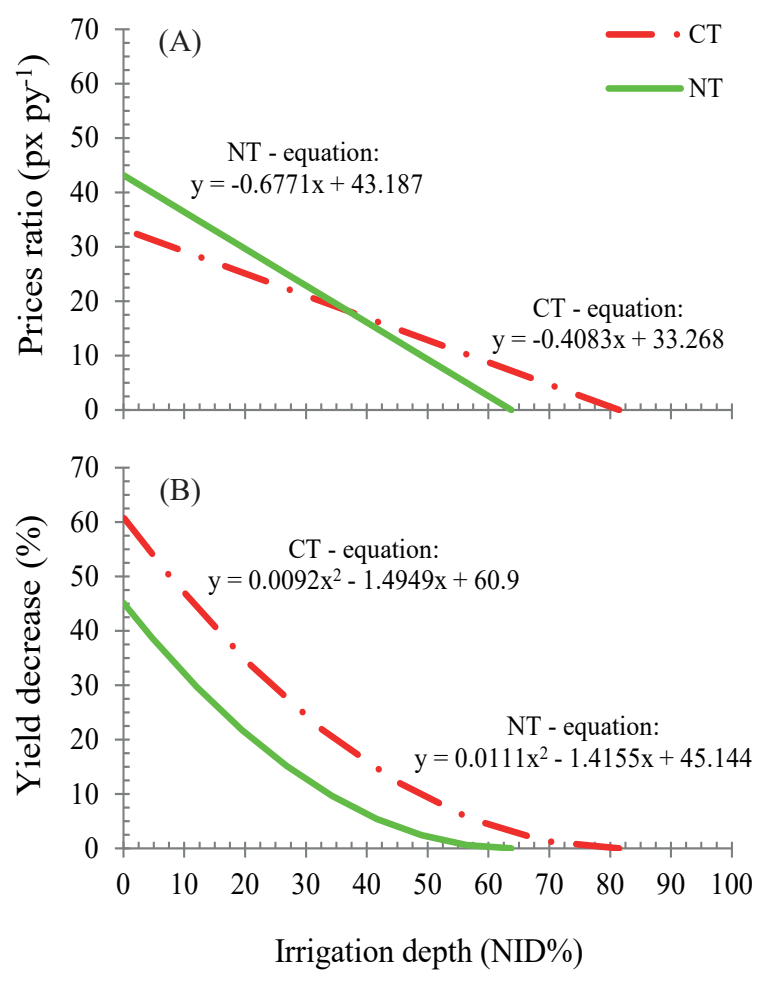

Figure 3. Relation between prices of water ( $\mathrm{px}$ in $\$ \mathrm{~mm}^{-1}$ ) and bean (py in $\$ \mathrm{~kg}^{-1}$ ) $(\mathrm{A})$ and bean grain yield decrease (B), as a function of net irrigation depth percentage (NID\%).

\section{CONCLUSIONS}

1. The grain yield in the no-tillage system was $26.5 \%$ higher than in the conventional tillage, since the mass of 100 seeds showed no difference for the type of soil management;

2. The grain yield had a polynomial quadratic response to the irrigation depths applied in both the soil management systems, and the mass of 100 seeds had a decreasing linear response;

3. No-tillage systems should be preferred, and a $36.2 \%$ decrease in the applied water depth had no negative effect on the bean yield;

4. Rain-fed agriculture systems would be economically feasible only when the ratio of prices between water and bean is equal to 33.27 and $43.19 \mathrm{~kg} \mathrm{~mm}^{-1}$, respectively for the conventional tillage and no-tillage systems.

\section{ACKNOWLEDGMENTS}

The authors would like to thank the Instituto Agronômico do Paraná (Iapar), Londrina/PR unit, for providing the bean seeds of the 'IPR Andorinha' cultivar.

\section{REFERENCES}

ALLEN, R. G.; PEREIRA, L. S.; RAES, D.; SMITH, M. Crop evapotranspiration guidelines for computing crop water requirements. Rome: FAO, 1998.

ALVARES, C. A.; STAPE, J. L.; SENTELHAS, P. C.; CONÇALVES, J. L. M.; SPAROVEK, G. Köppen's climate classification map for Brazil. Meteorologische Zeitschrift, v. 22, n. 6, p. 711-728, 2013.

ARF, O.; RODRIGUES, R. A. F.; SÁ, M. E.; BUZETTI, S.; NASCIMENTO, V. Manejo do solo, água e nitrogênio no cultivo de feijão. Pesquisa Agropecuária Brasileira, v. 39, n. 2, p. 131-138, 2004.

BORTOLUZZI, D. D.; PRADO, G.; HARA, A. T.; SOUZA, A. C. S. Precipitação mensal provável no noroeste do Paraná. Revista Brasileira de Agricultura Irrigada, v. 13, n. 2, p. 3314-3326, 2019.

CARAMORI, P. H.; GONÇALVES, S. L.; WREGE, M. S.; CAVIGLIONE, J. H.; OLIVERIA, D.; FARIA, R. T.; LOLLATO, M. A.; MARIOTI, E. J.; KRANZ, W. M.; PARRA, M. S.; BIANCHINI, A. Zoneamento de riscos climáticos e definição de datas de semeadura para o feijão no Paraná. Revista Brasileira de Agrometeorologia, v. 9, n. 3, p. 477-485, 2001.

COMPANHIA NACIONAL DE ABASTECIMENTO (Conab). Acompanhamento da safra brasileira de grãos. Brasília, DF: Conab, 2020.

CONCEIÇÃO, C. G.; ROBAINA, A. D.; PEITER, M. X.; PARIZI, A. R. C.; CONCEIÇÃO, J. A.; BRUNING, $\mathrm{J}$. Economically optimal water depth and grain yield of common bean subjected to different irrigation depths. Revista Brasileira de Engenharia Agrícola e Ambiental, v. 22, n. 7, p. 482-487, 2018.

FARIA, M. T.; TURCO, J. E. P.; FERNANDES, E. J.; GUIRRA, A. P. P. M. Resposta produtiva do feijoeiro comum a diferentes manejos de irrigação. Irriga, v. 17, n. 2, p. 137-147, 2012.

FERREIRA, D. F. Sisvar: a computer statistical analysis system. Ciência e Agrotecnologia, v. 35, n. 6, p. 10391042, 2011.

FIDALSKI, J.; HELBEL JUNIOR, C. Available water content for the management of irrigated crops in the northwestern region of Paraná state. Revista Brasileira de Agricultura Irrigada, v. 14, n. 2, p. 3976-3986, 2020.

FIDALSKI, J.; TORMENA, C. A.; ALVES, S. J.; AULER, P. A. M. Influência das frações de areia na retenção e 
disponibilidade de água em solos das formações Caiuá e Paranavaí. Revista Brasileira de Ciência do Solo, v. 37, n. 3, p. 613-621, 2013.

FISCHER FILHO, J. A.; ZOCOLER, J. L. Estimativa do coeficiente de cultivo $(\mathrm{Kc})$ do feijoeiro em Ilha Solteira, SP. Engenharia na Agricultura, v. 23, n. 3, p. 138-147, 2016.

FOOD AND AGRICULTURE ORGANIZATION (FAO). World reference base for soil resources. Rome: FAO, 2015.

KASSAM, A.; FRIEDRICH, T.; DERPSCH, R. Global spread of conservation agriculture. International Journal of Environmental Studies, v. 76, n. 1, p. 29-56, 2019.

KOTZ-GURGACZ, T.E.; SORATTO, R.P.; GUIDORIZZI, F. V. C. Foliar and topdressing application of nitrogen to the common bean crop. Pesquisa Agropecuária Brasileira, v. 53, n. 12, p. 1329-1337, 2018.

LEAL, F. T.; FILLA, V. A.; BETTIOL, J. V. T.; SANDRINI, F. O. T.; MINGOTTE, F. L. C.; LEMOS, L. B. Use efficiency and responsivity to nitrogen of common bean cultivars. Ciência e Agrotecnologia, v. 43, n. 1, p. 1-13, 2019.

MAHGOUB, N. A.; IBRAHIM, A. M.; ALI, O. M. Effect of different irrigation systems on root growth of maize and cowpea plants in sandy soil. Eurasian Journal of Soil Science, v. 6, n. 4, p. 374-379, 2017.

MARCO, K.; DALACORT, R.; FARIA JUNIOR, C. A.; FREITAS, P. S. L.; VILLELA, T. G. Aptidão agroclimática e características agronômicas do feijão comum semeado na safra das água em Tangará da Serra/MT. Enciclopédia Biosfera, v. 8, n. 15, p. 160-170, 2012.

MENDOZA-PÉREZ, C.; SIFUENTES-IBARRA, E.; OJEDA-BUSTAMANTE, W.; MACÍAS-CERVANTES, $\mathrm{J}$. Response of surface-irrigated corn to regulated deficit irrigation. Ingeniería Agrícola y Biosistemas, v. 3, n. 1, p. 29-40, 2016.

MiOTO, L. S.; ARAUJO, M. A.; SERON, C. C.; LAVANHOLI, R.; BATISTA, M. A.; LOZANO, C. S. Resistência do solo à penetração das raízes avaliada por dois penetrômetros em uma área cultivada com mandioca. Acta Iguazu, v. 5, n. 1, p. 65-79, 2016.

MIRALLES, D. G.; BRUSTSAERT, W.; DOLMAN, A. J.; GASH, J. H. On the use of the term "evapotranspiration". Water Resources Research, v. 56, n. 11, e2020WR028055, 2020.

MOREIRA, G. B. L.; PEGORARO, R. F.; VIEIRA, N. M. B.; BORGES, I.; KONDO, M. K. Desempenho agronômico do feijoeiro com doses de nitrogênio em semeadura e cobertura. Revista Brasileira de Engenharia Agrícola e Ambiental, v. 17, n. 8, p. 818-823, 2013.
OLIVEIRA, E. L. Sugestão de adubação e calagem para culturas de interesse econômico no estado do Paraná. Londrina: Iapar, 2003.

PEREIRA, H. S.; MELO, L. C.; DI PRADO, P. R. C.; MELO, P. G. S.; FARIA, L. C.; SOUZA, T. L. P. O.; AGUIAR, M. S.; CABRERA DIAZ, J. L.; ALMEIDA, V. M.; COSTA, A. F.; MELO, C. L. P.; CARVALHO, H. W. L.; PEREIRA FILHO, I. A. Cultivares de feijão com maiores teores de ferro, zinco e proteina nos grãos. Brasília, DF: Embrapa, 2018.

PEREIRA, V. G. C.; GRIS, D. J.; MARANGONI, T.; FRIGO, J. P.; AZEVEDO, K. D.; GRZESIUCK, A. E. Exigências agroclimáticas para a cultura do feijão (Phaseolus vulgaris L.). Revista Brasileira de Energias Renováveis, v. 3, n. 1, p. 32-42, 2014.

PRADO, G. Water distribution from medium-size sprinkler in solid set sprinkler systems. Revista Brasileira de Engenharia Agrícola e Ambiental, v. 20, n. 3, p. 195-201, 2016.

PRADO, G.; MAHL, D.; TINOS, A. C.; SCHIAVON, R. A. Produtividade do amendoim submetido a lâminas de irrigação e sistemas de preparo do solo. Enciclopédia Biosfera, v. 18, n. 37, p. 446-459, 2021.

PRADO, G.; TINOS, A. C.; MAHL, D.; SCHIAVON, R. A. Produtividade do milho irrigado na região do Arenito Caiuá no noroeste do Paraná. Irriga, v. 25, n. 3, p. 465480, 2020.

SANTOS, H. G.; JACOMINE, P. K. T.; ANJOS, L. H. C.; OLIVEIRA, V. Á.; LUMBRERAS, J. F.; COELHO, M. R.; ALMEIDA, J. A.; ARAÚJO FILHO, J. C.; OLIVEIRA, J. B.; CUNHA, T. J. F. Sistema brasileiro de classificação de solos. 5. ed. Brasília, DF: Embrapa, 2018.

SORATTO, R. P.; ARF, O.; RODRIGUES, R. A. F.; BUZETTI, S.; SILVA, T. R. B. Resposta do feijoeiro ao preparo do solo, manejo de água e parcelamento do nitrogênio. Acta Scientiarum: Agronomy, v. 25, n. 1, p. 89-96, 2003.

TELleS, T. S.; RIGHeTtO, A. J.; COSTA, G. V.; VOLSI, B.; OLIVEIRA, J. F. Conservation agriculture practices adopted in southern Brazil. International Journal of Agricultural Sustainability, v. 17, n. 5, p. 338346, 2019.

THOMAZ, E. L.; FIDALSKI, J. Interrill erodibility of different sandy soils increases along a catena in the Caiuá sandstone formation. Revista Brasileira de Ciência do Solo, v. 44, e0190064, 2020.

VOLSI, B.; BORDIN, I.; HIGASHI, G. E.; TELLES, T. S. Economic profitability of crop rotation systems in the Caiuá sandstone area. Ciência Rural, v. 50, n. 2, e20190264, 2020. 